\title{
The Austrian school of Madrid
}

\section{Cristóbal Matarán López ${ }^{1}$ (iD}

Accepted: 3 January 2021 / Published online: 26 January 2021

(C) The Author(s) 2021

\begin{abstract}
This paper focuses on the current situation and the historical development of Austrian Economics in Madrid. We will analyse the formation of this School as the result of the thesis defended by Joaquín Reig Albiol in the late fifties and the current economic debate surrounding the fractional reserve and other complex issues. In this half-century tour, we will explore three different generations of Austrian economists in Spain, whilst demonstrating that a distinct branch of the Austrian School is today live and well in Madrid. Eventually, we will discover how the Spanish Austrian economists have applied praxeology to contemporary political and economic problems and conclude that a vigorous and growing economic school of thought exists in Madrid.
\end{abstract}

Keywords History of the economic thought $\cdot$ Methodology $\cdot$ History of the economic ideas . Austrian economics

JEL classification B25 $\cdot$ B31 $\cdot$ B53 $\cdot$ N14

\section{The birth of the Austrian school ${ }^{1}$}

\subsection{The Spanish roots of the Austrian school}

The Austrian School of Economics was born in Vienna (at that time, AustrianHungarian Empire), in 1871 when Carl Menger published his Principles of Economics. Menger rediscovered the subjective economic analysis that the Spanish Scholastics elucidated in the sixteenth century (J. Huerta de Soto, The Spanish Roots of the Austrian School de Soto Jesús 2009). His main contribution was to refute the objective

\footnotetext{
${ }^{1}$ The author wishes to thank Professor Philipp Bagus (King Juan Carlos University) and M. Torquil Mathewson for their comments and corrections. Remaining errors are all mine.
}

Cristóbal Matarán López

cristobal.mataran@universidadeuropea.es

1 Department of Economics and Business, Faculty of Social Sciences and Communication, European University of Madrid, 28024 Villaviciosa de Odón, Madrid, Spain 
theory of labour, an amalgam of theories originating from the Classical British School, in which value could be calculated objectively due to cost of production, labour or salaried labour.

Thus, Menger laid the groundwork of a school of thought in which marginalism, subjectivism and entrepreneurship roots were to be found in the Spanish Scholastics, most of them Dominicans and Jesuits (Rothbard 1995; Rothbard 2006). The founder of the School of thought was Francisco de Vitoria, who many consider to be the first philosopher of International Law. He concluded that natural law is superior to state law, but without reflecting upon how markets operate.

Diego de Covarrubias y Leyva, who became bishop of Segovia, was the first thinker in the School of Salamanca to set forth the subjective theory of value. He stated that "the value of an article does not depend on its essential nature, but on the subjective estimation of men, even if that estimation is foolish" (Andrés et al. 2012).

Luis Saravia de la Calle further developed Covarrubias' concepts and came to the conclusion that costs follow prices, or, in the opposite sense, prices determine costs. That this was determined three centuries before the Classical School mentioned the work-value theory, is remarkable in itself. He further stated that "those who measure the just price by the labour, costs and risks incurred by the person who deals in the merchandise are greatly in error. "The just price is found not by counting the cost but by common estimation" (Saravia de la Calle [1544] de la Calle, Luis 1949). Saravia de la Calle also noted that bankers should be paid by the depositors instead of obtaining their gains by the practise of the fractional reserve.

Martín de Azpilcueta can be accurately ascribed to be the first thinker of the School of Salamanca to focus on monetary problems. He sketched out a brief and rudimentary version of the quantitative theory of value when he declared "money is worth more where and when it is lacking than where and when it is in abundance" (Azpilcueta [1556] de Azpilcueta 2011). In addition, he fervently opposed the practise of fractional reserve, arguing that a banker should be "warden, depositor and guarantor of the gold deposited in his strongbox" (Azpilcueta [1556] de Azpilcueta 2011).

Finally, Father Juan de Mariana wrote about several different topics, like the centralised rule of the Jesuit Company, monetary theory and the inflation caused by the arrival of metals coming from America. His main contribution, however, was his analysis about inflation caused by governmental debasement of coins, a fact that Juan de Mariana condemned as sheer robbery. This led to his development of a tyrannicide doctrine, according to which any citizen can commit tyrannicide against a ruler that imposes taxes without the consent of the people.

As we can observe, most of the topics covered by the Scholastics are still present in the debates of the Austrian School. They were indeed ahead of their time, especially when they began to judge inflation as a monetary phenomenon, to conceive the entrepreneur as a visionary who needs to value future events in order to make necessary expenditures today.

These thinkers set the stage for the following generations of Austrian economists including Menger, Eugen Böhm-Bawerk, Friedrich von Wieser, Ludwig von Mises, and F.A. Hayek. The work of these scholars, and especially the work of Mises served as the foundation for a unique branch of thought within the Austrian School of Economics. 


\subsection{Why the Austrian school?}

It is worth asking why the Austrian School has such dissemination, especially in academia, in Spain? Perhaps because there is a common substrate, that is, the search for scientific truth. There is a chronological order to be understood before one can understand the central role of the Austrian School in Spain.

Our path begins in the sixteenth century. In this period, the conquest of the New World had set up the Spanish Empire as the first world power. Therefore, it was that the Spanish universities became the leaders all over the world. In this context is when the School of Salamanca started its path. The authors from the second Scholastic led a reflection about the economic phenomena not in the sense that we conceive today, but in a moral sense. Nevertheless, the main point we have to focus on is that the Western investigation in economics didn't start in Great Britain in the eighteenth century.

In conclusion, the current study of subjectivism actually could be considered a happy return to the leading economic theory. The explanation of economic facts, like the economic cycle, the monetary theory or entrepreneurship belonged to the Spanish scientific heritage five centuries ago. The new challenges launched by a globalised world, like the euro, the deflationary process stopped by the central intervention, or increasing government spending and public debt, relied on the tools provided by the marginal subjectivism. Here is the first cause of its success.

Moreover, we cannot underestimate the importance of religion. While historians of economic thought, like Schumpeter, never took into account the religious beliefs of the different authors, others, like Rothbard, Viner or Hayek, placed much importance upon the religious education received by an author to explain his theories. Hence, it is not surprising that the economic subjectivism has travelled between two sociologically Catholic countries like Austria and Spain.

The third cause is found during the economic opening after Franco's autarky. After the worst two decades of economic policies in Spain, the situation reached its limits that required a radical solution. It was precisely the ministers of the Catholic branch of the government who started a new model of economic policy, much more based upon markets than in government intervention. This new economic policy, developed in 1959, was named the Stabilisation Plan. The main political consequence was that Spain ceased its traditional international isolation. In the academic field this opening coincided with the expansion of Austrian ideas thanks to the Reig Albiol brothers.

Thus, Spain became the principal bastion of the Austrian School in Western Europe due to, especially, the Reig Albiol brothers. To make a comparison, it would be like a relay race in which the Reig Albiol brothers would have taken the baton from the School of Salamanca. Spain would become one of the scarce meeting points of the subjectivist's tradition initiated in Vienna, near the end of the nineteenth century, in continental Europe. Little by little, the authors of the Austrian School of Madrid are taking positions in Academia, in order to find the final recognition.

The first Austrian seminar in Europe since Mises's exile was initially a meeting of like-minded friends, debating economic principles and the Spanish economy. Afterwards, the seminar moved to the Law Faculty at Complutense University of Madrid. It is worth noting that Hayek and Popper visited the seminar several times.

It is in this context that the generational change within the Austrian Spanish economists took place. For the very first time, even in a small size, the Austrian 
seminar took an academic aspect. The first lessons based on subjectivism, taken from the School of Salamanca, according to which a creative actor pursues his ends through scarce means, took place in the late 80's. This is when Professor Huerta de Soto started to build a new branch of the Austrian School.

Perhaps the final recognition arrived during the Great Recession (2008). At that time, the Western economies suffered the biggest and most generalised recession in three decades. Mainstream economic theory, which is not able to explain the underlying causes of Western economies sudden episodes of recession after long periods of boom, is additionally unable to provide suitable solutions. Essentially, the mainstream theories have a common substrate, that is, that the economies go into crisis because they do not spend as much as it would be necessary to employ all the economic factors. The multi-stage production or the effects of the savings over the productive structure are totally ignored (Hayek 1931). In essence, this economic theory was unable to understand why an economy required an inevitable correction, especially from the real estate assets, after a long period of credit expansion financed by the central banks.

It is here that the economic cycle provided by the Austrian School develops itself forcibly. A whole generation of economists had begun to search for new alternatives to face the traditional economic theories surrounding economic issues. Therefore, the comeback of an economic theory which seemed to be marginalised in academia, little by little started to take a front seat in the academic debate. We can quote some examples about how the Austrian Business Cycle Theory has been mentioned in different academic journals or books, not only in those with an Austrian perspective. In Huerta de Soto, Jesús (1980a, b), Alonso et al. (2013), Rallo (2011), Alonso et al. (2011a, b). All these examples are Austrian perspectives of the recent recession, but published in what we could consider mainstream journals. In fact, the Great Recession had just shown how the Austrian marginalism could be used not only in economic theory, but in many other fields. From the traditional neoclassical synthesis, academia is starting to reflect upon its own failures. This debate could end up in the middle term to a changing paradigm.

\section{The origins of the Austrian School of Madrid}

There are prior and discernible influences earlier in the twentieth century that are worth mentioning. Professor Luis de Olariaga Pujana (1885-1976) prepared a doctoral thesis in Germany during the 1930's after discovering Hayek's work and translated some of Hayek's papers and essays, becoming the first Spanish translator of the Austrian School essays. Subsequently, professor Olariaga taught at the London School of Economics, holding dialectical clashes with the mainstream Keynesian theoreticians (Velarde Fuentes 1986).

The origins of the Austrian School of Madrid are circa 1957, when Spain faced its second dictatorship government under General Franco. The economic policy was strongly socialist during the first two decades of Francoism: interventionist in prices and wages, economic planification and nationalisations of some strategic sectors, like energetic supply or industry. The result of these policies were scarcity and economic underdevelopment. 
After the implementation of the Stabilisation Plan (1959), the Spanish economy experienced its best growth of the twentieth century, paradoxically after the worst. The Spanish population experienced real income growth not seen since the rise of the Industrial Revolution a century and a half before. Unemployment fell and, for the first time, a middle urban class seemed able to finance previously unthinkable luxuries, such as holidays.

It is in this economic context that Joaquín Reig Albiol wrote his doctoral thesis "The Modern Social Problems Under the Economic Ideology of Ludwig von Mises" (Joaquín 1957). M. Reig Albiol was born in 1922 (Matarán 2017). His first and great influence on liberal thought came initially from his father, Joaquín Reig Rodríguez, a Spanish MP during the II Republic and editor of a liberal magazine, El Camí. This magazine followed the principles of liberal nationalism, a way of thinking in which freedom is taken as the main guiding principle.

Going back to the aforementioned thesis, it consists of a travel through the ideas and contributions of Mises for half a century. It is divided into seven chapters, one for each theory of Mises work: socialism, monetary theory, entrepreneurship, methodology, value theory, economic interventionism, and labour organisation. Finally, the thesis offers several conclusions.

Firstly, the ends of the economic actors cannot be judged by a third person. These ends are subject to specific situations and circumstances that can better be judged by the actor with the help of ethics. Second, entrepreneurship, as conceived as the way of looking for profits and new opportunities, is the only suitable and accurate way of organising economic production. The scarcity is gradually reduced when entrepreneurship could develop to allocate scarce resources. Third, the impossibility of organising society by use of coercive methods. In this way, market prices are not the best, but the only way of allocating scarce resources, in line with what was explained in the previous chapter. Fourth, socialism, as a result of controlling prices and wages, relentlessly drives political intervention and a lack of human rights. Fifth, regulation induces the same economic consequences as intervention in prices and wages, but in a more subtle way. Sixth, national trade is ruled by the same economic rules as international trade. All attempts to decrease or guide it in a specific way results in counter productivity. Seventh, inflation especially impoverishes people whose incomes depend more on work than on capital. Eighth, labour, as any other scarce asset, follows the same economic laws as any other productive factor. Ninth, economic freedom and political freedom go hand in hand. ${ }^{2}$ Tenth, Reig Albiol makes a deep distinction between taxation necessary to finance a minimum and legitimate State, in which security, defence and a lasting social network could be justified, to another one based upon confiscation and economic planning. Eleventh, socialism needs a permanent state of war to develop. On the contrary, liberalism proclaims freedom of act and thought. Twelfth, and last, the bigger the State, the more enemies it would need to create to keep its size.

Two years after the publication of Reig Albiol's thesis, the first version of Human Action was published, translated to Spanish by Reig Albiol himself in the following years. This publication went ahead thanks to the sponsorship of Ignacio Villalonga Foundation, a Spanish non-profit organisation dedicated to publishing books and

\footnotetext{
${ }^{2}$ When this thesis was defended (1958), Spain was under the dictatorship of General Franco, a nationalsyndicalism regime in which human rights were not respected. We can find in the thesis some passages in which the author tries to make clear that he is not criticising Franco's government.
} 
essays about liberalism, founded by the banker Ignacio Villalonga, Reig Albiol father's friend. As Margrit, widow of Mises, pointed out: "Ludwig's most ardent readers and admirers always have been in the Spanish-speaking countries. Apparently, the more subjugated the country is, the deeper the longing of freedom" (von Mises 1976). From that moment on, all reprints of Human Action and later translations about Mises's essays were supervised by Reig Albiol.

And so, the Austrian School had finally penetrated the academic Spanish world, even if it was still in its infancy. In addition to this editorial work, Joaquín Reig Albiol and his brother Luis organised (for two decades) privately held seminars on economics and freedom. A sixteen-year-old student named Jesús Huerta de Soto started to attend these seminars.

The second major influence of the Austrian School in Spain did not come from a Spanish author, but from a British thinker. Marjorie Grice-Hutchinson (19092003) wrote her doctoral thesis under Hayek's leadership in the London School of Economics before settling in Spain. It reveals that the roots of the Austrian School were to be found in the School of Salamanca (Grice-Hutchinson 1952).

Professor Carmelo Viñas Rey, a Spanish specialist about Mercantilism in Castille, recommended Grice-Hutchinson read Professor's José Larraz essay La Época del Mercantilismo en Castilla (Larraz 1943). It was after discussing this essay with Hayek that Grice-Hutchinson focused her investigations upon the Spanish Scholastics of the Sixteenth century (Perdices, Luis, et al. 2010).

Third, Professor Lucas Beltrán (1911-1997) encapsulates the perfect example of a Spanish thinker, formed under the leadership and direction of Austrian economists. After graduating in Law in Hayek 1931, he began his doctoral thesis in the London School of Economics with Hayek and Robbins. His retirement in 1981 was commemorated with a tribute book (Carande et al. 1982), which featured distinguished authors such as Gottfried Haberler and Lionel Robbins, demonstrating the international recognition which Professor Beltrán commanded.

Lastly, there is an Austrian precedent in Spain, not only in academia, but also in politics in the figure of Alberto Ullastres (1914-2001), finance minister of Franco's regimen and the greatest ideological supporter of the Stabilisation Plan. He gained the doctoral degree in 1941 with a thesis titled "Las Ideas Económicas de Juan de Mariana”, with professor Olariaga presiding the academic tribunal (Ullastres 1945).

As previously stated, Reig Albiol defended a doctoral thesis about Mises in the late fifties. At that moment, Mises, whose most prominent work, "Human Action", appeared just eight years before, was still alive. He was yet to publish some of his best essays, like Theory and History (1957) and The Ultimate Foundation of Economics (1962). So, the thesis defended by Reig Albiol only focused on Mises' work prior to these publications. The thesis was directed by Professor Jesús Prados Arrate. The committee qualified the thesis with a cum laude.

\footnotetext{
${ }^{0}$ When this thesis was defended (1958), Spain was under the dictatorship of General Franco, a nationalsyndicalism regime in which human rights were not respected. We can find in the thesis some passages in which the author tries to make clear that he is not criticising Franco's government.
} 


\section{The consolidation of the Austrian School of Madrid}

\subsection{First steps of the Austrian School of Madrid}

After the publication of Reig Albiol's thesis, the Austrian School of Madrid remained practically forgotten within academia. However, the 1973 oil crisis was an opportunity to change the dominant paradigm of the time. The inability of the Keynesian model to explain supply inflation, added to accelerating unemployment, provided an opening for the Spanish Austrian economists. The opportunity for the Austrian School of Madrid was ripe, but as the school of thought was still in its infancy, it was unable to dominate the economic landscape.

However, at the beginning of the eighties, the second generation of the Austrian School of Madrid started to take over and one name emerged amongst all the others: Jesús Huerta de Soto. In September 1983, Huerta de Soto became an assistant professor at Complutense University of Madrid and the private seminars he was involved in became more public and academic. Emulating the model that Ludwig von Mises instituted in Vienna and New York, Huerta de Soto gathered together people interested in economics, politics or philosophy from an Austrian perspective. The aim of these seminars was to establish a debatable framework around the Austrian principles, applied to the current situation in Spain.

This development was followed by the establishment of "Unión Editorial", the first publishing house of Austrian School essays in Spanish. Unión Editorial was founded in 1973. ${ }^{3}$ Endowed with the amount of 700.000 pts., the central role of the new publishing house was to translate into Spanish the classical works of Austrian economists. In the late 80's, Professor Huerta de Soto acquired a small stake in the company.

\subsection{The arrival of Jesús Huerta de Soto}

As we quoted before, in September 1983, Professor Huerta de Soto started as an associate professor at Complutense University of Madrid, specifically in the Faculty of Law. His intellectual background from that time forward are of immense significance and have led towards the significance with which the Austrian School of Madrid is currently held in different academic fields.

Jesús Huerta de Soto was born in Madrid in 1956. After he graduated in Law and Economics at the Complutense University of Madrid, with a grant paid by the Bank of Spain in Stanford University (Wang 2017). He taught Economics in Complutense University from 1984 to 2000, when he was promoted to full-time Professor in the new-born King Juan Carlos University. He subsequently became one of the most prominent and relevant celebrities of the Austrian School in the Spanish-speaking world.

His thinking is both prolific and original, developing and refining the work of previous Austrian thinkers and improving many of them in different ways, like his Three Levels Theory. It is rare that a new thinker emerges in economic

\footnotetext{
${ }^{3}$ A few years before, there was an organisation called Ignacio de Villalonga Foundation, a certain kind of think tank founded by the banker who gave the name to it. This organisation was set up not to provide specifically a liberal or Austrian vision of the Spanish politics, but to develop some courses or seminars about economics, specially banking. Nevertheless, his founder and most of its members, like the Reig Albiol brothers, were fervent admirers of the Austrian School.
} 
theory who is able to set up a new branch of thought within their area of study and this has not taken place since the formation of the School of Salamanca.

About his prominence and impact in academia, we can find out that he is one of the most quoted Spanish authors at this moment. ${ }^{4}$ He has obtained three six-year research, the certification delivered by the Spanish government to an equivalent period of research and publications. Besides, seven of his books are available in the Library of Congress (J. Huerta de Soto, Library of Congress s.f.).

\subsubsection{Main contributions}

Mises (von Mises 1951; von Mises 1962) quoted the impossibility of socialism based on the inability of planners to engage in economic calculation due to, in the first place, the inexistence of private property, which enables the absence of market prices. As a result of this, the debate about the economic calculation made a clean sweep in academia throughout all the twentieth century. Socialism could never work out problems surrounding the allocation of scarce resources. Entrepreneurial projects could not be valued in a rational way, due to the inexistence of market prices which set up the limits for viable and nonviable companies.

Although the socialist debate took place in the 1920s and 1930s of the last century, Professor Huerta de Soto provided a new vision based on the dynamic conception of entrepreneurship. Indeed, he identifies a new vision by basically re-defining the term. Socialism means nationalisation of the means of production. Professor Huerta de Soto changes the definition to mean what Mises called "interventionism" and what was later called the "dynamics of interventionism" (Ikeda 2015). This is important because it is grounded in a definition of socialism that most scholars, including Mises, would not recognize. ${ }^{5}$ Thus, the new definition provided by Professor Huerta de Soto claims:

"We will define 'socialism' as any system of institutional aggression on the free exercise of entrepreneurship. By aggression or coercion, we mean all physical violence or threats of physical violence which another person or group of people initiates and employs against the actor. As a result of this coercion, the actor, who otherwise would have freely exercised his entrepreneurship, is forced, in order to avoid greater evils, to act differently than he would have acted in other circumstances, and thus to modify his behaviour and adapt it to the ends of the person or persons who are coercing him" (Huerta de Soto 2010).

Therefore, a new concept of efficiency emerges. If we suppose that efficiency is a dynamic concept (leaving behind the neoclassical conceptions about static efficiency) then we can conclude that efficiency is both economic in nature and ethical. In the paper The Theory of Dynamic Efficiency (Huerta de Soto 2008), Professor Huerta de Soto redefines efficiency by drawing on contributions from different economists (not only Austrians) throughout the history of the economic thought. In summary, he points

\footnotetext{
${ }^{4}$ DialNet, probably the best search engine about scientific papers and books, shows fifty papers, twelve collaborative works, eighteen books, two doctoral thesis, forty-one thesis directed and one collaborative book.

${ }^{5}$ In recent times, Professor Huerta de Soto has recognised that his definition of socialism would be more suitable to be called "interventionism" (de Soto, Jesús 2010).
} 
out that the Austrian concept of efficiency, which builds upon all previous conceptualisations, should take precedence over the neoclassical concept, based only on optimisation. As Professor Huerta de Soto points out:

"The static conception of economics reduces the principle of economic efficiency to a simple technical issue of maximization, which in any case could be resolved with a mere computer into which someone would enter the data always presumed known in the models of static efficiency" (Huerta de Soto 2008, 8).

In the field of money and banking, Professor Huerta de Soto published Money, Credit Bank and Economic Cycles (1998), perhaps his most quoted and debated essay (J. Huerta de Soto, Money, Credit Bank and Economic Cycles de Soto Jesús 2012). In this book, Professor Huerta de Soto explained how the practise of the fractional reserve over the last five centuries has entailed recurrent episodes of irrational exuberance, followed by the consequent recession. The proposed solution is to head toward a financial system based upon a non-central banking regulator.

From this perspective, the creation and entry into circulation of the Euro has generated many unintended consequences. The possibility that the member States of the monetary union cannot manipulate the currency has turned the euro into an approximation to the gold standard (Huerta de Soto 2013). Of course, we cannot assume that the euro is exactly a gold standard system, but some of its features are implicit in the euro system.

In the field of the history of economic thought, Professor Huerta de Soto has pointed out how the Austrian School sank its roots in the School of Salamanca, during the sixteenth century (Huerta de Soto, Jesús 2020a, b). Thus, this group of priests and religious Catholics reached some conclusions clearly ahead of their time. A subjective theory of value, the rate of interest or entrepreneurship are some of the ideas that were correctly pointed out by these members two centuries before Adam Smith supposedly invented economics.

In the political field, professor Huerta de Soto has focused his investigations under his "Three-Level Theory", which is in essence a combination of rules through which a thinker could judge certain actions as appropriate (Huerta de Soto 1988-1989). Such actions could be large scale political initiatives, right down to individual actions. These rules should be judged under three different perspectives: ethical, historical, and theoretical. Should all the three tests be passed, then we can accept this course of action as correct. As professor Huerta de Soto sums up:

"Thus, following this model, it is easy to understand how any erroneous policy always arises as the result of a chain of factors which correspond to each of these three levels. In fact, behind any policy which is harmful to society, there are usually, at a strictly theoretical level, serious scientific errors, and fallacies. Effectively, false theories are continually being used to justify the most harmful interventionist policies. Sometimes, these theories emerge independently, by chance, and policies are subsequently adopted as a consequence of the theoretical and methodological errors committed. On many other occasions, however, erroneous theories are constructed ad hoc in order to justify certain policies which have been decided previously" (Huerta de Soto 2010, 186). 
This analysis has motivated Professor Huerta de Soto's vision about interventionism, not only as a theoretical impossible, but also as immoral and a permanent historical failure. In addition, Professor Huerta de Soto has become one of the most prominent and resolute defenders of the Anarchocapitalism, that is, the full and complete privatisation of all goods and services. In this sense, he points out that public goods in the middle of a market economy resemble islands in the middle of the ocean, that is, goods and services produced without the guidance of prices (Huerta de Soto 2009).

\subsubsection{Master's degree in Austrian economics}

Without any doubt, one of the most decisive step in the dissemination of this concrete branch of one school of economic thought, that moment in which this group of thinkers could be considered a real trend in Academia, is the moment in which the Master's Degree in Austrian Economics started its development in 2007. Located in King Juan Carlos University of Madrid (Vicálvaro), this Master's degree provides an entire knowledge of Austrian Economics tradition in one school year. The course, as well, is divided into eleven subjects and a final project thesis. In the first of them, the studies consist of methodology, national defence, microeconomics, economic thought and a seminar about dynamic efficiency. In the second one, we continue with technology, monetary theory, macroeconomics, public policies, theory of spontaneous order and a seminar about socialism. In addition, to get the Master level, it is compulsory for all students to write a final thesis, around forty pages long, a subject of the student's choosing in which to develop the knowledge acquired about Austrian Economics. The essays are graded by a committee formed by three members, one of them a Professor of another university to guarantee the independence of the process.

We do not contend that the Austrian School of Madrid did not exist before the creation of the Master's Degree, rather that it is final recognition that the city of Madrid hosts the most prominent and leading group of Austrian researchers in Europe. In fact, there had not been such a large group of researchers and thinkers about the Austrian School tradition since pre-World War I Vienna. In fact, some of Professor Huerta de Soto's students, like Óscar Vara, Javier Aranzadi, Ángel Rodríguez and César Martínez were already awarded with a Ph.D.

A preliminary analysis might conclude that the Master consists of many postgraduate studies that currently fill up the Spanish universities. However, the rigour of the Austrian School method ensures new researchers obtain a solid basis for further investigations. It is considered a Master's Degree not only with a focus on economists who desire to begin an economic career, but to every person interested in the Austrian School and its principles. In fact, it encompasses subjects from economics to matters more analytic, like defence or technology.

In conclusion, it is not possible to understand what the Austrian School of Madrid has achieved without understanding the importance of this Master's Degree. For the first time in history, students can find complete and in-depth analysis of the Austrian School in a variety of academic fields: monetary theory, methodology, history of economic thought, etc.

The huge number of students that have emerged from these studies has created a real branch of one school of thought and, even more importantly, guarantees the future of the research in the field. In fact, some of the most relevant figures of the Austrian 
tradition, not only in Spain but in all of South America, went through the King Juan Carlos University classrooms, like Juan Ramón Rallo, Adrián Ravier, Miguel Ángel Echarte and David Sanz, to name a few.

\subsubsection{The international doctoral school}

One of the fundamental issues to build a true branch of a concrete school of thought is the creation of a group of students that can continue and build upon the work carried out by the previous generation. The first step, as we have just seen in the previous section, was the creation of a regular school year to study the Austrian School. The second one, is the creation of a group of students who, according to an exegesis process, will continue the Austrian tradition in Spanish academia. They will provide new and genuine contributions to economics, philosophy, history and other fields in the social sciences. ${ }^{6}$

At the beginning of the third decade of the twenty-first century, forty candidates had achieved the Ph.D. degree under Professor Huerta de Soto's guiadance. Names like Juan Ramón Rallo, Adrián Ravier, Óscar Vara, Javier Aranzadi, Gabriel Calzada, Ángel Rodríguez, Miguel A. Alonso and Philipp Bagus, all wrote their Ph.D. thesis under Professor Huerta de Soto's leadership.

For instance, Phillip Bagus wrote about "Deflation: Is It Really Harmful?” (2007). Years after, the thesis was published (Bagus 2015). Professor Bagus theorises about a type of good deflation, that is, the gradual reduction of the amount of money in circulation due to an increasing number of goods and services available to the citizens. Another thesis (written in English) was carried out by Professor David Howden under the title Financial Asset Pricing Under Knightian Uncertainty (Howden 2010). Professor Howden makes a deep critique to the neoclassical concept of Paretian efficiency to judge the rationality of investments. In this sense, the author asks for a new model of dynamic efficiency based upon creativity, that is, the Austrian concept of entrepreneurship. Therefore, the most important issue in finance at this historical moment is to turn down the neoclassical way of thought - the optimisation of phantasmagorical mathematical functions. Additionally we have Massimiliano Neri's, "The Economics of the Knowledge Structure" (Neri 2011), Marc Schelling's "Mergers and Acquisitions within the Austrian Business Cycle" (Schelling 2013) and Brian C. Canny's "The Theory of Optimum Currencies and a Critique of the Theory of Optimum Currency Areas" (Canny 2016) also completed their Ph.D. in English. These examples are evidence of the impact of scholar's working in the Austrian School in Madrid.

\subsubsection{Procesos de Mercado}

All branch of one school of economic thought should have its own way to develop a space for debates. In the academic field, the creation and distribution of a scientific review seems to be the most suitable method to achieve a position into academia. With this in mind, Procesos de Mercado. Revista Europea de Economía Política appeared

\footnotetext{
${ }^{6}$ We can quote the example of Nicole Oresme, who made several contributions in different fields of human knowledge, becoming a forefather of the Renaissance. Nevertheless, his work remained hidden for over a century until Francisco de Vitoria rescued it.
} 
for the first time in Calzada 2004. Despite its title, it is not only addressed towards economists. Its multidisciplinary approach encompasses all social sciences, with papers in history, politics, law, sociology, etc. In addition, the review accepts papers in Spanish, English or French.

Professor Huerta de Soto is the director and founder of the review. Professors María Blanco, Gabriel Calzada, Javier Aranzadi, Antonio Martínez, Ángel Rodríguez and Óscar Vara execute as deputy directors. The Editorial department is formed by Professors Miguel A. Alonso and Philipp Bagus, Editor and Deputy Director, respectively. Finally, David Howden, Juan Ramón Rallo and Sonsoles Huerta de Soto perform as deputy assistants. The review is formed by a scientific counsel set up with professors and professionals from many different fields. Their main function is called blind peer review. Procesos de Mercado is published one per semester, that is, an issue in autumn and another in spring.

Regarding its content, the review is structured in different parts. The first one is focused on more academic Papers, at least, thirty pages long. They are truly scientific papers, some of them presented as lectures in economic meetings or congress. Their numbers vary from four to six in each issue. In the second place, we find the Notes. These are papers, but shorter. For instance, talks at economic meetings or articles about polemic issues in the nation's politics are published here. They search for the clarification on a concrete issue, without the extension of a scientific paper. Then there is a Documents section where there are published extracts from the classical essays of the Austrian School, especially from the works of Hayek and Mises. The next section is about Bibliographic Review. It addresses the summary of recent or classical books about all fields in the social sciences and informs the read of new and interesting content.

After this, we find out what could be the most original section in the review, the News. There one can find the latest events, meetings, lectures and so on that are taking place, not only in Madrid but in many different cities, from all the members of the Austrian School of Madrid. In the last place, the review ends with a Suggestion for New Readings. There, in a laudable effort by Professors Alonso and Bagus, the Editors make a tour of all the media, mentions to the Austrian School or its members, not only Spanish but from all over the world, in the last six months. That is, this section works as a press release.

\section{Other outstanding members of the Austrian School of Madrid}

In this section we are going to look over the most prominent and distinguished leading figures in the current Austrian School of Madrid. We can start our review from what we can call the second generation of the Austrian economists in Madrid, that is, from the late nineties to the present. As we will see, most of these members have in common their stay in the Doctoral School. This academic centre has begun what we can name as the youth academy of the Spanish-speaking Austrian economists.

The unifying thread of all these contributions is the continuation of the classical Austrian Economics tradition. Nevertheless, we can appreciate an important feature. Before the Great Recession (2008), almost all of the academic works were about all the fields in economics. We can find the monetary theory of Miguel A. Alonso or Philipp 
Bagus, the economic thought of Óscar Vara, David Sanz or Javier Aranzadi, the essays about the American economy from David Howden or the studying of the Second Scholastic from Professor Gómez Rivas. As we mentioned before, it is starting from the Great Recession when the Spanish mainstream academia suffered a huge shock in scientific production. From that very moment, the monetary questions related to the economic cycle have practically monopolised the debate within the Austrian School of Madrid. The mainstream provided numerous explanations for the Great Recession. Nevertheless, those interpretations clash with those ones provided by the members of the Austrian School of Madrid. In fact, these original reasons are getting more and more recognition in the Spanish academia.

In fact, this diffusion has crossed our borders. The fact that the Western economies have had to fight with a recession of worldwide characteristics has entailed that the Austrian Economics, forgotten and marginalised for centuries, had experienced a resurrection, not only on the national level, but on the international level. ${ }^{7}$

\subsection{Miguel a. Alonso}

Professor Alonso developed his academic career in the Department of Applied Economics at King Juan Carlos University as an associate professor, a job that he combined with the subject of Macroeconomics in the Austrian Economics Master. His research focus is economic cycles and their relationship with the movements of capital. Monetary policy, as well as the impact of taxes over the international capital markets has entailed an impact on them. His research activity has provided him the opportunity to be published in journals like the CESifo Economic Studies, European Journal of Law and Economics, Interdisciplinary Journal of Economics and Business Law, Open Journal of Modelling and Simulation, Hacienda Pública Española, Trimestre Económico, Revista de Economía Mundial or Investigación Económica. In addition, he works as editor in chief of the journal Procesos de Mercado, as we have referred to previously.

His doctoral thesis dealt with the problems of controlling the financial capitals and the impact of taxes over them (Alonso Neira 2004). As we can read in the abstract:

"The volume of international capital movements has multiplied in the last decade. Forces that have led savers and lenders to international capital markets include the modernization of telecommunications and information technology, as well as the relaxation of capital controls. However, the liberalization of financial markets has also entailed significant challenges for national governments. In this sense, the international monetary crises of the nineties have broken the apparent consensus that existed regarding the process of financial liberalization, stimulating debate on the desirability of taxing international capital movements. This paper analyses the impact and effectiveness of capital controls, understood as barriers to intertemporal trade, using dynamic models" (Alonso Neira 2001, ii).

\footnotetext{
${ }^{7}$ For instance, if we check the website Web Of Science (Science s.f.), we can find out that Professor Huerta de Soto is getting 2.55 quotes every year in academic papers, Professor Alonso Neira is getting a 1.14, and Professor Bagus 9.90. In order to making a comparison, Julio Seguro, who presided the Spanish regulatory agency for the financial markets, achieves a 3.86 .
} 
On one hand, Alonso Neira studies the volatility of the current currency markets and focuses his attention on the government controls through the central banks and the abandonment of the gold standard in the seventies. Besides, the model of twin crisis (Alonso et al. 2004), that is, monetary and banking, one consequence of the other, it is staged through a historical event: the Asian crisis of 1997-1998. On the other hand, Alonso Neira confronts the arguments for and against the controls over the financial system, as well as restrictions more or less deeper, adding to the essay the incidence of these controls over the price of the productive factors. His conclusion is that controls over capital entail an increase over business costs, especially in labour. Finally, Alonso Neira asks himself if a fee would be possible over financial transactions, commonly known in the Western countries as Tobin Fee, which started to be developed in Sweden in 1984 and eventually abolished in 1991. The Tobin Fee has become the warhorse issue of the anti-globalisation movement since the eighties. Due to the capital being the most volatile and least affected economic factor, a fee of $0.5 \%$ on the financial transactions turned out to be such a failure that, at the end of the experiment, the volume of the futures market had decreased 98\% (Wrobel 1996).

\title{
4.2 Philipp Bagus
}

Professor Bagus (2015) obtained his Ph.D. in Economics at King Juan Carlos University with a study of the effects of deflation on the economic system. Besides, Bagus provides an opportunity to know the traditional arguments against the effects of deflation over the productive structure. Eight years later, the essay was published. According to the abstract:

\begin{abstract}
"This book analyses the causes and consequences of deflation. In contrast to the widespread belief that deflation would be harmful to the economy as a whole, the author argues that free market deflation is liberating and beneficial. Several myths of deflation are exposed and the reasons for the widespread deflation phobia that serves to justify expansionary monetary policy, i.e., inflation are investigated. Two historical case studies, the growth deflation in the US after the Civil War and the bank credit deflation in Germany during the Great Depression are discussed to illustrate the points made in the theoretical analysis of deflation." (Bagus 2015, i).
\end{abstract}

After earning his degree, Bagus started a successful career in the study of macroeconomics, especially in the monetary system. For instance, Bagus has been published in several journal, including the Journal of Business and Ethics, European Journal of Law and Economics, Revista de Economía Mundial, Información Comercial Española and Libertarian Papers. In addition, he is deputy editor of the Quarterly Journal of Austrian Economics and Procesos de Mercado. In relation to private institutions, he is a member of Mises Institute, the Property and Freedom Society and the Mont Pelerin Society. Finally, he obtained many awards and recognitions, like the Ron Paul Liberty in Media Award, the Ludwig Erhard Förderpreis für Wirtschaftspublizistik, the Gary G. Schlabaum Prize and the O.P. Alford III Prize.

His research focuses on on the first hand, on the monetary policy followed by the central banks as a consequence of the Great Recession (2008). In an original 
interpretation of the fiduciary system, Bagus maintains that one of the unintended consequences of monetary policies is the redistribution of the income in favour of certain groups, in a clear example contrary to the free market distributor mechanism. On the other hand, Bagus (2012) published an essay about how the euro has become an obstacle to the stabilization of the monetary policy. Indeed, Bagus points out the euro has become a tool for the Southern government (Spain, Italy above all) not not take into consideration their macroeconomics problems, especially chronical deficits and public debt. Bagus concludes that the monetary policy carried out by the ECB has been laxer than that made by the Bundesbank.

\subsection{Gabriel Calzada}

Professor Calzada constitutes a curious case. He is not only a well-known person who had made the corresponding contributions to the intellectual heritage of the Austrian School of Madrid, but also, from his position as chancellor of the Francisco Marroquín University, has contributed, in a decisive way, to bear the name of the Austrian School to the Hispanic-American world.

In his doctoral thesis, Calzada (2004) analyses the possibility of a private security provision through insurance companies, the same line of investigation followed by other Austrians, like Hoppe (2003) and Block (2018). To the ultimate extent, what is proposed is the theory of overlapping government, a type of social organisation according to which each individual would negotiate with the company he deems appropriate. This, in turn, would provide the basic security and justice services that, traditionally, have been reserved to the state action. In case of litigation with another person, it would be the insurance companies that were responsible for facing a resolution. The cost of an open confrontation would be so high that it would discourage all aggression.

As for his academic function, Calzada started his career at the King Juan Carlos University. Nevertheless, it was later, and thanks to his move to Francisco Marroquín University, when his career, and therefore the dissemination process of the Austrian School of Madrid, took a step forward. In 2011 he joined as deputy rector and two years after, as rector. In addition, Calzada is a senior fellow of the Ludwig von Mises Institute.

However, if Calzada stands out for something within the Austrian School of Madrid, it is for having founded the first liberal think tank in the country. After enjoying a scholarship at the Mises Institute, Calzada returned to Spain with the intention of creating a similar institution that was gaining influence over the years. After an interview, Huerta de Soto recommended Calzada that the nascent organisation should be named after one of the members of the School of Salamanca. The result was the establishment of the Juan de Mariana Institute. ${ }^{8}$

On the other hand, Calzada has become one of the most prominent scholars on the impact of environmental legislation on the economy. In a certain way, it is an application of a discipline, the economic analysis of law, which emerged in the second

\footnotetext{
${ }^{8}$ It should be clarified that the Institute is not a purely Austrian think tank, since the confrontation of ideas is also sought within the liberal movement, not only with respect to other more interventionists schools of thought.
} 
half of the twentieth century and seeks to scrutinise the effects on the economic growth of the legislation. Calzada began in this line of research following the publication of the report on the incidence of the renewable energy subsidy policy carried out by the Spanish government since Calzada 2004 (Calzada et al. 2009). Especially relevant was his activity in the press, with countless articles and appearances in television and radio debates to point out the enormous cost of renewable energy subsidies policies, added to their low efficiency. Ultimately, Calzada has pointed out that the cause of this obsession with renewable energy lies in a mistaken belief about avoidable climate change and, worse, a consequence of the action of human beings on the planet.

\subsection{Juan Ramón Rallo}

Professor Rallo has become one of the most prominent academic disseminators, not only of Austrian thought, but about all the liberal principles in the media. In his Ph.D. thesis, Rallo (2011) tries to focus on a theoretical explanation of the Great Recession (2008), due to the instrumental analysis that the Austrian School provides. The thesis is divided into two main blocks. In the first part, Rallo tries to develop a synthesis of the classical business Austrian theory, on one hand, and the newest liquidity theory, on the other hand, raised from the last investigations of Fekete. In the second part, Rallo carries on a historiographic journey through all the immediate previous years to the Great Recession and the public policies set out by the Western governments. Especially relevant is his proposal of a bail-in rescue to the banks, instead of all the government policy, from right to left, for a bail-out.

Nevertheless, where Rallo has stood up has been, as we previously pointed out, in the media. For a decade now, Rallo has been a regular in both television and radio gatherings to provide his point of view about the economic situation, always from an Austrian perspective.

At the research level, Rallo (2011) has written an essay making a deep critique to Keynesian Economics. The work consists of a refutation of Keynes's General Theory grounded in the analytical tools provided by the Austrian School. This book's title is a clear tribute to Henry Hazlitt (2007). Besides, Rallo made another huge critique to the universal basic income, a policy consisting of providing all citizens with an income. This basic income, extended to all the population, has become one of the most important policies proposed by the welfare State supporters (Rallo 2015a, b). ${ }^{9}$ Their argument is that capitalism does not provide a basic income to the most vulnerable people, so its implantation will be necessary.

\subsection{David Howden}

As with Bagus, Professor Howden is another example of a member of the Austrian School of Madrid born in a foreign country. After graduating in finance at the Waterloo University (Canada), he earned a master's degree in Austrian Economics and wrote a doctoral thesis titled Financial Asset Pricing Under Uncertainty (Howden 2010). he currently teaches economics and finance at St. Lous University (Madrid). His

\footnotetext{
${ }_{9}^{9}$ Even many proponents of market/capitalism argue for some form of a basic income to replace the existing welfare state.
} 
contributions have been focused on the Austrian business cycle theory and into a devastating critique to the monetary policy followed by the Federal Reserve after the Great Recession.

Howden has devoted numerous articles to this topic, pointing out, as a trigger for a multi-year depression, the central banks refusal to let the economy reap the malinvestments induced during the recession. In addition, he has cited how the refusal of central banks to allow market forces to redirect macroeconomic imbalances to a stabilising path is at the opposite of what could be considered a market economy (Howden 2014).

\section{Conclusions}

The first conclusion we can reach is about the importance of the Austrian School of Madrid to scholars. Apparently, to Spanish students and professors interested in the tradition of the Austrian School, the emergence of a branch of thought whose principles are based upon these ideas, entails a place to exchange opinions and contributions. But the popularity of the Austrian School of Madrid provides a huge opportunity due to the historical situation of Spain. That is, on the one hand, we have seven hundred million people speaking in Spanish all over the world, especially in America. This constitutes a golden opportunity to pass on the Austrian tradition to places that have been less prone until now. On the other hand, the Spanish situation as a member of the European Union allows Spanish scholars to disseminate the Austrian tradition in other European countries. These two characteristics only could be found in a country like Spain.

In the second place, we find the Austrian tradition, which submerged its roots in the Scholastics of the Spanish Golden Age, has gone back home. Thus, the advances in economics have a new point of interest in the current situation of the Austrian School of Madrid. We could affirm that it is about the joyful return home of the subjectivist tradition.

Therefore, we have to conclude that the Austrian School of Madrid is constituted as one more branch, with its own idiosyncrasy, within the Austrian School. Nevertheless, its situation is just at the dawn. In particular, the influence of two generations within this branch of thought can be traced: the first one, leaded by Reig Albiol brothers, and the second one, leaded by Huerta de Soto.

Open Access This article is licensed under a Creative Commons Attribution 4.0 International License, which permits use, sharing, adaptation, distribution and reproduction in any medium or format, as long as you give appropriate credit to the original author(s) and the source, provide a link to the Creative Commons licence, and indicate if changes were made. The images or other third party material in this article are included in the article's Creative Commons licence, unless indicated otherwise in a credit line to the material. If material is not included in the article's Creative Commons licence and your intended use is not permitted by statutory regulation or exceeds the permitted use, you will need to obtain permission directly from the copyright holder. To view a copy of this licence, visit http://creativecommons.org/licenses/by/4.0/.

\section{References}

Alonso, N. (2001). Controles de Capital, Variables Financieras y Política Económica. Madrid: King Juan Carlos University (unpublished ph.d.). 
Alonso, N. (2004). Teoría de las crisis monetarias y financieras y de los controles de capital. Madrid: Instituto de Estudios Económicos.

Alonso, N., Ángel, M. \& Blanco Jiménez, F, J. (2004). «Los modelos de 'crisis gemelas’ en el marco de la literatura sobre crisis monetarias internacionales.» Crisis monetarias y financieras internacionales JulyAugust, $n^{\circ} 816: 75-92$.

Alonso, N., Ángel, M., Bagus, P. \& Rallo, J, R. (2011a). «La Crisis Subprime a la Luz de la Teoría Austriaca del Ciclo Económico: Expansión Crediticia, Errores de Decesión y Riesgo Moral.» Revista de Economía Mundial, $\mathrm{n}^{\circ} 28: 145-174$.

Alonso, N., Ángel, M., Bagus, P. \& Rallo, J, R. (2011b). «Teoría del Ciclo Económico: Principales Contribuciones y Análisis a la Luz de las Aportaciones de la Escuela Austriaca de Economía.» Información Comercial Española (ICE): Revista de Economía, $\mathrm{n}^{\circ} 858$ : 71-87.

Alonso, N., Ángel, M., Bagus, P. \& Ania, A, R. (2013). «Una Ilustración Empírica de la Teoría Austriaca del Ciclo Económico: El Caso de Estados Unidos, 1988-2010.» Investigación Económica LXXII, $\mathrm{n}^{\circ} 285$ : 41-74.

Andrés, S., Javier, F., \& Martín, I. P. (2012). Diego de Covarrubias y Leyva: El Humanista y sus Libros. Salamanca: Ediciones Universidad de Salamanca.

Azpilcueta, M. de [1556] (2011). Comentario Resolutorio de Cambios. Madrid: Fundación Ignacio Larramendi.

Bagus, P. (2012). The Tragedy of Euro. Auburn, Albama: Ludwig von Mises Institute.

Bagus, P. (2015). In Defence of deflation. Londres: Springer.

Block, W. (2018). Defending the Undefendable. Auburn, Alabama: Ludwig von Mises Institute.

Calzada, G. (2004). Análisis económico e institucional de la teoría de la defensa privada a través de las compañias de seguros. Madrid: King Juan Carlos University (unpublished ph.d.).

Calzada, G., Merino, R., \& Rallo, J. R. (2009). Study of the effects on employment of public aid to renewable energy sources. Public Policies, Madrid: Juan de Mariana Institute.

Canny, B. C. (2016). The Theory of Optimum Currencies and a Critique of the Theory of Optimum Currency Areas. Madrid: King Juan Carlos University (unpublished thesis).

Carande, R., Casas Pardo, J., \& de Ayala, J. L. P. (1982). Homenaje a Lucas Beltrán. Madrid: Editorial Moneda y Crédito.

de Soto, J. H. (2010). Socialism, Economic Calculation and Entrepreneurship. London: Edward Elgar in association with the Institute of Economic Affairs.

de la Calle, Luis, S. (1949). Instrucción de Mercaderes. Madrid: Joyas Bibliográficas.

Huerta de Soto, Jesús. (1988-1989). «Conjectural History and Beyond.» Humane Studies Review VI, n 1 : 10.

Huerta de Soto, Jesús. (2008). «The theory of dynamic efficiency.» en The Theory of Dynamic Efficiency, de Jesús Huerta de Soto, 1-30. New York: Routledge Foundations of the Market Economy.

Huerta de Soto, Jesús. (2009). Classical liberalism versus Anarchocapitalism. In J. G. de Hulsmann \& S. Kinsella (Eds.), En Property and Freedom Society. Essays in Honor of Hans-Hermann Hoppe (pp. 161178). Auburn, Alabama: Ludwig von Mises Institute.

Huerta de Soto, Jesús. (2009). "The Spanish roots of the Austrian school.» en The Theory of Dynamic Efficiency, de Jesús Huerta de Soto, 263-275. New York: Routledge Foundations of the Market Economy.

de Soto, Jesús, H. (2010). «A Hayekian strategy to implement free markets reforms.» en The Theory of Dynamic Efficiency, de Jesús Huerta de Soto, 182-199. New York: Routledge Foundations of the Market Economy.

Huerta de Soto, J. (2010). «Socialismo y Descivilización.» Procesos de Mercado. Revista Europea de Economía Política (Unión Editorial) IX, $\mathrm{n}^{\circ} 1: 343-352$.

de Soto Jesús, H. (2012). Money, Credit Bank and Economic Cycles. Auburn (Alabama): The Ludwig von Mises Institute.

Huerta de Soto, Jesús. «In Defence of the Euro: An Austrian Perspective» Journal des Economistes et des Études Humaines 1, n 19 (2013): 1-28.

de Soto Jesús, H.. «Juan de Mariana and the Spanish Scholastics.» Jesús Huerta de Soto. Professor of Applied Economics (King Juan Carlos University, Madrid). 27th de November de 2020a. https://www. jesushuertadesoto.com/articulos/articulos-en-ingles/juan-de-mariana-and-the-spanish-scholastics/.

de Soto Jesús, H.. Library of Congress. s.f. https://id.loc.gov/authorities/names/n84129079.html (último acceso: 30th de November de 2020b).

Grice-Hutchinson, M. (1952). The School of Salamanca. Readings in Spanish monetary theory, 1544-1605. Oxford: Clarendon Press.

Hayek, F. A. (1931). Prices and production. New York: August M Kelly, Publishers. 
Hazlitt, H. (2007). The failure of new economics. Auburn (Alabama): The Ludwig von Mises Institute.

Huerta de Soto, Jesús. (1980a). «La Teoría Austriaca del Ciclo Económico.» Cuadernos de Economía: Spanish Journal of Economics and Finance VIII, $\mathrm{n}^{\circ} 22$ : 257-272.

Huerta de Soto, Jesús. (1980b). «La Teoría Austriaca del Ciclo Económico.» Moneda y crédito, n 52 : 37.

Hoppe, H.-H. (Ed.). (2003). The Myth of National Defense. Essays on the Theory and History of Security Production. Editado por Hans-Hermann Hoppe. Auburn, Alabama: Ludwig von Mises Institute.

Howden, D. (2010). Financial asset pricing under uncertainty. King Juan Carlos University: Unpublished doctoral thesis.

Howden, D. (2014). «Knowledge Flows and Insider Trading.» Review of Austrian Economics XXVII, n 1 : 45-55.

Ikeda, S. (2015). Dynamics of Interventionism. Regulation and Redistribution in the Mixed Economy. Vol. VIII. In P. de Boettke \& J. Christopher (Eds.), Coyne de The Oxford Handbook of Austrian Economics (pp. 21-57). Oxford: Emerald Group Publishing.

Joaquín, R. A. (1957). Los Modernos Problemas Sociales a la Luz del Ideario Económico de Ludwig von Mises. Madrid: Central University of Madrid (unpublished thesis).

Larraz, J. (1943). La Época del Mercantilismo en Castilla. Madrid: Atlas.

Matarán, C. (2017). «Joaquín Reig Albiol, el Primer Austriaco Español.» Procesos de Mercado. Revista Europea de Economía Política (Unión Editorial) XIV, n 2 : 239-246.

Neri, M. (2011). The Economics of the Knowledge Structure. Madrid: King Juan Carlos University (unpublished thesis).

Perdices, L., \& Baumert, T. (2010). La Hora de los Economistas. Entrevistas a Cuarenta Economistas que han Contribuido a la Modernización de la Economía Española. Madrid: Ecobook.

Rallo, J. R. (2011). Una aplicación de la teoría del ciclo económico desde la perspectiva de la Escuela Austriaca a la Gran Recesión. Madrid: King Juan Carlos University.

Rallo, J. R. (2015a). Contra la Modern Monetary Theory. Los siete fraudes inflacionistas de Warren Mosler. Madrid: Unión Editorial.

Rallo, J. R. (2015b). Contra la Modern Monetary Theory: Los Siete Fraudes Inflacionistas de Warren Mosler. Madrid: Unión Editorial.

Rothbard, M. N. (1995). An Austrian Perspective in the History of the Economic Thought. Editado por ltd. Edward Elgar publishing. Vol. Vol. I. Economic thought before Adam smith. Auburn, Alabama: Ludwig von Mises Institute.

Rothbard, M. N. (2006). An Austrian Perspective in the History of the Economic Thought. Editado por ltd. Edward Elgar publishing. Vol. Vol. I. Economic thought before Adam smith. Auburn, Alabama: Ludwig von Mises Institute.

Saravia de la Calle. (1544). Instrucción de Mercaderes. Madrid: Joyas Bibliográficas.

Schelling, M. (2013). Menger and Acquisitions within the Austrian Business Cycle. Madrid: King Juan Carlos University (unpublished thesis).

Science, Web Of. Clarivate Analytics. s.f. https://apps.webofknowledge.com/UA_GeneralSearch_input.do? product=UA\&search_mode=GeneralSearch\&SID=F14UPxOqhkntTgDoWHU\&preferencesSaved= (último acceso: 2nd de December de 2020).

Ullastres, A. (1945). «La Teoría de la Mutación Monetaria del Padre Juan de Mariana.» Anales de Economía, : 273-303 and 453-471.

Velarde Fuentes, J. (1986) «Luis de Olariaga en su centenario.» Anales de la Real Academia de Ciencias Morales y Políticas, 283-293.

von Mises, L. (1951). Socialism. An Economic and Sociological Analysis. New Haven: Yale University Press. von Mises, L. (1962). Socialism. An Economic and Sociological Analysis. New Haven: Yale University Press. Mises, M. von (1976). My years with Ludwig von Mises. New York: Arlington House.

Wang, W, H. (2017). «Jesús Huerta de Soto: The Synthatiser of the Austrian School.» Procesos de Mercado. Revista Europea de Economía Política XIV, n 2 : 173-203.

Wrobel, M. G. (1996). The financial transactions taxes: The international experience and the lessons for Canada. Ottawa: Research Branch.

Publisher's note Springer Nature remains neutral with regard to jurisdictional claims in published maps and institutional affiliations. 